\title{
Pengaruh Pembayaran Dividen Terhadap Kinerja Keuangan Perusahaan Pada Perusahaan Manufaktur Di BEI
}

\author{
Putri Nuriksani ${ }^{1}$ dan Verina Puspa Sari ${ }^{2}$ \\ ${ }^{1,2}$ Universitas Trisakti \\ Email Address: \\ putri.nuriksani13@gmail.com
}

\begin{abstract}
Abstrack: The purpose of this study is to understand the effect of dividend policy on a company's financial performance. This article examines the research gap and then builds a research model using ROA as the dependent variable, dividend rate and dividend payment decision as independent variables, and firm size, leverage, and income growth as control variables. This paper collects data and financial reports from 196 companies from the manufacturing sector listed on the Indonesia Stock Exchange from 2016 to 2020. The results of the analysis show that dividend payment decisions have no effect on manufacturing companies as measured by the financial performance of accounting-based companies but this raises expectations. the market for the company. In addition, this paper finds that manufacturing companies offer low dividend rates which have a positive impact on the company's financial performance but have a negative effect on market expectations. This paper offers some informative results-based recommendations, including better dividend policy models, lower dividend yields, and clearer dividend payment decisions.
\end{abstract}

Keyword: dividend rate, dividend policy, company financial performance, leverage, manufacturing.

\begin{abstract}
Abstrak: Tujuan dari penelitian ini adalah untuk mengetahui pengaruh kebijakan dividen terhadap kinerja keuangan perusahaan. Artikel ini mengkaji kesenjangan penelitian dan kemudian membangun model penelitian dengan menggunakan ROA sebagai variabel dependen, tingkat dividen dan keputusan pembayaran dividen atau variabel independennya, dan ukuran perusahaan, leverage, lalu pertumbuhan pendapatannya sebagai variabel kontrol. Makalah ini mengumpulkan data dan laporan keuangan dari 196 perusahaan dari sektor manufaktur yang terdaftar di Bursa Efek Indonesia dari tahun 2016 hingga tahun 2020. Hasil analisis menunjukkan bahwa keputusan pembayaran dividen tidak berpengaruh pada perusahaan manufaktur yang diukur dengan kinerja keuangan akuntansi- perusahaan berbasis tapi ini menimbulkan harapan. pasar bagi perusahaan. Selain itu, makalah ini menemukan bahwa perusahaan manufaktur menawarkan tingkat dividen rendah yang berdampak positif pada kinerja keuangan perusahaan tetapi memiliki efek negatif pada ekspektasi pasar. Makalah ini menawarkan beberapa rekomendasi berbasis hasil yang informatif, termasuk model kebijakan dividen yang lebih baik, hasil dividen yang lebih rendah, dan keputusan pembayaran dividen yang lebih jelas.
\end{abstract}

Kata Kunci: tingkat dividen, kebijakan dividen, kinerja keuangan perusahaan, leverage, manufaktur. 


\section{PENDAHULUAN}

Pertembuhan perekonomian di Indonesia dapat dikatakan begitu pesat setelah mengalami tekanan akibat pandemic covid-19 pada tahun 2020. Pertumbuhan perekonomian di Indonesia tidak terlepas dari peran perusahaan yang bergerak di bidang industri manufaktur. Di triwulan II tahun 2021 perusahaan manufaktur memberi kontribusi terbesar pada pertumbuhan ekonomi di Indonesia mencapai 7,07\%. Manufaktur menjadi sumber pertumbuhan tertinggi sebesar 1,35\%. Meski mendapat tekanan dari pandemi Covid 19 , industri manufaktur sendiri tumbuh $6,91 \%$ selama periode tersebut. Beberapa subsektor yang naik di tengah tekanan COVID-19 adalah 45,70\% untuk industri alat angkut, industri logam dasar dengan presentasenya $18,03 \%$, industri mesin serta peralatan 16,35\%, 11,72\% untuk industry karet serta produk plastik, industri kimia dan farmasi serta obat tradisional dengan presentase 9,15\%. (https://kemenperin.go.id).

Pertumbuhan industri manufaktur membuat persaingan antar perusahaan di Indonesia semakin ketat. Memiliki asset yang tinggi tidak menjamin suatu bisnis perusahaan dapat bertahan dan berkembang. Perusahaan harus memiliki keunggulan kompetitif yang kuat dan memiliki kinerja yang baik. Keberhasilan bisnis perusahaan ditandai dengan tercapainya tujuan perusahaan yaitu memaksimalkan laba dan mensejahterahkan pemegang saham. Laba perusahaan yang bertumbuh tinggi dapat menggambarkan kondisi kinerja perusahaan yang baik pula. (Dewi \& Candradewi, 2018).

Kinerja keuangan perusahaan yang tinggi menandakan keefektifan dan keefesianan perusahaan dalam mengelola sumber dayanya. Investor dapat tertarik pada suatu saham perusahaan ketika kinerja keuangan tersebut dalam kondisi yang stabil dan baik. Kinerja keuangan dapat dihitung menggunakan return on asset (ROA) (Matar \& Eneizan, 2018). Kinerja keuangan dapat dikatakan baik jika memiliki nilai perusahaan yang tinggi. Setiap perusahaan akan berusaha memaksimalkan nilai perusahaannya dengan membuat keputusan pembayaran dividen atau ditahan menjadi laba ditahan.

Kebijakan pembayaran dividen mempunyai peranan penting pada setiap perusahaan. Keputusan untuk membayar dividen akan menjaga citra perusahaan tetap baik. Hal tersebut akan memiliki pengaruh kuat terhadap laba perusahaan. Setiap perusahaan memiliki pertimbangannya untuk menetapkan berapa besar dividen yang akan dibayarkan kepada para pemilik saham (Ullah \& Bagh, 2020).

Dividend payout ratio mempunyai fungsi sebagai cerminan kondisi keuangan suatu perusahaan dengan membandingkan jumlah jumlah dividen yang dibagikan terhadap laba per lembar saham. Dalam membeli saham pada suatu perusahaan dividend payout ratio yang memadai akan menjadi pertimbangan bagi seorang investor. Perusahaan yang membagikan dividennya setiap periode akan lebih diminati oleh para calon investor untuk menanamkan modal dan akan menaikkan kinerja keuangan perusahaan (Dharma et al., 2020)

Ukuran perusahaan digambarkan dengan jumlah aset yang dimilikinya. Semakin besarnya jumlah asset yang dimiliki perusahaan, oleh sebab itu kinerja keuangannya semakin besar pula. Leverage berfungsi sebagai pengambilan keputusan sumber pendanaan dengan membandingkan nilai hutang dengan nilai modal sendiri tujuannya yaitu untuk meningkatkan keuntungan pemilik saham. Keputusan sumber pendanaan tersebut dapat mempengaruhi kinerja keuangan perusahaan (Dewi \& Candradewi, 2018). Growth perusahaan 
dapat mempengaruhi kinerja keuangan, tingkat pertumbuhan yang tinggi dari suatu perusahaan maka perusahaan tersebut mampu meningkatkan laba perusahaan (Indra Widjaja, 2019). Sektor manufaktur menjadi tempat penelitian pada artikel ini dengan alasan sesuai latar belakang yang telah diuraikan.

\section{KAJIAN TEORI}

Kinerja Keuangan Perusahaan. Kinerja keuangan perusahaan adalah posisi keuangannya yang dipengaruhi oleh proses pengambilan keputusan manajemennya. Kinerja keuangan menjadi kompleks sebab berkaitan dengan efisiensi modal serta kinerja perusahaan. Kinerja perusahaan dianggap sebagai sumber pertumbuhan ekonomi yang berkelanjutan, pada saat proses pengambilan keputusan berinvestasi menjadi salah satu faktor penting untuk dianalisis investor. Kinerja perusahaan juga penting bagi pemangku kepentingan lainnya, seperti manajer, kreditur, karyawan, dan negara. Pada pengukuran kinerja keuangan perusahaan belum ada consensus di antara peneliti-peneliti (Silvestro, 2014)

Prinsip teoritis yang mendasari pengaruh kebijakan dividen terhadap kinerja perusahaan dapat dijelaskan dalam teori relevansi dividen yang dikemukakan oleh (Deni, 2018.). Menurut teori yang dikemukakannya bahwa harga saham serta biaya modal tidak mengalami dampak dari kebijakan dividen, artinya kebijakan dividen perusahaan kurang relevan untuk kekayaan pemegang saham sesuai dengan asumsi pasar modal yang sempurna. (Deni, 2018) mengungkapkan analisis yang dirancang dengan baik tentang hubungan antara kebijakan dividen, pertumbuhan, dan penilaian saham.

Dividend Payout Ratio. Bagi calon investor serta para pemilik saham perusahaan penting untuk mengathui informasi dividen yang dibagikan guna menunjukkan pendapatan yang dihasilkan perusahaan. Pembayaran dividen yang sehat dengan demikian menunjukkan bahwa perusahaan menghasilkan pendapatan nyata. Sebuah studi oleh (Ping \& Ruland, 2006) mengungkapkan bahwa perusahaan dengan pembayaran dividen yang tinggi cenderung mengalami pendapatan masa depan yang kuat tetapi pertumbuhan pendapatan masa lalu yang relatif rendah meskipun pengamat pasar memiliki pandangan yang bertentangan. Temuan studi lain yang dilakukan oleh (Arnott \& Asness, 2003) juga mengungkapkan bahwa pertumbuhan laba masa depan dikaitkan dengan pembayaran dividen yang tinggi daripada rendah.

(Litzenberger et al., 1982) menunjukkan bahwa kebijakan dividen mempengaruhi perilaku investor sebagai akibat dari disparitas perpajakan atas dividen dan capital gain. Penulis percaya bahwa investor lebih memilih bisnis dengan dividen rendah karena jumlah pajak yang harus dibayar diminimalkan. (Jensen \& Meckling, 1976) menyatakan bahwa ada tradeoff dalam bentuk biaya keagenan antara memiliki lebih banyak atau lebih sedikit kepemilikan orang dalam. Biaya agensi tercipta ketika manajer juga mengendalikan investasi orang luar selain miliknya sendiri, karena ada konflik kepentingan yang mendasar.

H1: Pengaruh Rasio Pembayaran Dividend berpengaruh positif Kinerja Keuangan Perusahaan. 
Decision of dividend payment. Tujuannya adalah untuk mengetahui dampak kebijakan dividen terhadap kinerja perusahaan. Temuan dari ini dapat berkontribusi pada literatur dengan mengkonfirmasi penelitian sebelumnya. Selain itu, dapat membantu manajer perusahaan menetapkan pedoman dividen untuk perusahaan publik yang dapat menyatukan arus kas dan kinerja keuangan mereka (Nguyen et al., 2021).

Model yang diterima sebelumnya dengan ROA sebagai variabel yang digunakan, sehingga rasio pembayaran dividen dan keputusan pembayaran dividen (nilai biner) merupakan variabel bebas. Data berasal dari laporan keuangan tahunan perusahaan publik yang telah diaudit dari tahun 2009 hingga 2013. Penulis melaporkan bahwa pembayaran dividen memiliki pengaruh yang signifikan terhadap kinerja perusahaan yang diukur.

H2: Keputusan Pembayaran Dividen berpengaruh negative terhadap Kinerja Keungan.

Ukuran Perusahaan. Ukuran perusahaan mewakili ukuran perusahaan. Besar kecilnya perusahaan dilihat dari luas wilayah kegiatan yang dilakukan. Anda dapat menentukan ukuran perusahaan Anda berdasarkan total penjualan, total neraca, dan tingkat penjualan rata-rata (Handayani, 2011). Ukuran perusahaan adalah ukuran yang dapat diklasifikasikan berdasarkan ukuran bisnis seperti ukuran total aset, ukuran pers, harga pasar, dll. Ukuran suatu perusahaan juga dapat diukur menggunakan nilai pasar dari saham perusahaan, ratarata penjualan, dan jumlah penjualannya. Ukuran perusahaan yang besar dan berkembang dapat mewakili tingkat profitabilitas masa depan. Pembiayaan sederhana ini dapat berdampak pada nilai perusahaan dan dapat dijadikan informasi yang baik bagi investor (Prasetia et al., 2014). Ukuran perusahaan mencerminkan perusahaan berkembang dan tumbuh dengan baik, sehingga nilai perusahaan semakin meningkat. Meningkatnya nilai perusahaan dapat dibuktikan dengan bertambahnya total aset dan semakin besar pula total kewajiban perusahaan.

H3: Ukuran Perusahaan berpengaruh negative terhadap Kinerja Keuangan Perusahaan.

Leverage Keuangan. Leverage keuangan sangat penting untuk membentuk kinerja organisasi. Banyak perusahaan menggunakannya sebagai strategi bisnis utama mereka untuk bersaing di pasar. Ini mengemukakan bagaimana perusahaan menggunakan biaya keuangan tetapnya. (Deni, 2018), memperkenalkan keuangan, menyimpulkan bahwa tidak adanya pajak perusahaan tidak bergantung pada utang. Leverage keuangan mempengaruhi kebijakan pembagian dividen karena efektif mengubah dividen perusahaan. Aturan yang digunakan pemberi pinjaman untuk dividen juga berlaku untuk pembagian dividen. Kami menggunakan rasio utang jangka panjang terhadap total aset untuk mewakili leverage. Perusahaan dengan leverage keuangan yang tinggi membayar lebih sedikit bunga (Farahani \& Ghara Jhafari, 2013). Manajemen leverage menjadi penting karena leverage yang tinggi dapat meningkatkan nilai perusahaan untuk perlindungan pajak. Leverage adalah rasio yang menghitung berapa banyak uang kreditur yang telah ditransfer, serta rasio yang membandingkan total kewajiban perusahaan dengan total asetnya, sehingga ketika investor melihat perusahaan menggunakan banyak aset tetapi juga memiliki risiko leverage yang tinggi, mereka diinvestasikan. 
H4: Leverage Keuangan Perusahaan berpengaruh negative terhadap Kinerja Keuangan Perusahaan.

Pertumbuhan Pendapatan. Tingkat pertumbuhan adalah rasio yang mengukur posisi perusahaan dalam industri secara keseluruhan dan kemampuannya untuk mempertahankan posisinya dalam pembangunan ekonomi. Tingkat pertumbuhan tersebut terlihat dari penjualan perusahaan, dividen per saham, harga pasar per saham, laba setelah pajak (EAT) dan laba per saham. Jika nilai pertumbuhan pendapatan positif, maka meningkatkan penjualan dari tahun ke tahun. Jika nilainya negatif, penjualan menurun dari tahun ke tahun (Fahmi, 2011).

H5: Pertumbuhan Pendapatan berpengaruh positive terhadap Kinerja Keuangan Perusahaan.

Rerangka Konseptual. Dividen adalah pembagian keuntungan perusahaan terhadap para pemilik sahamnya. Jika suatu perusahaan menghasilkan laba atau surplus, ia dapat membagikan sebagian dari laba itu kepada pemegang saham sebagai dividen. Sisa laba setelah dividen, laba ditahan, akan diinvestasikan kembali di masa depan (Nguyen et al., 2021).

Pembayaran dividen yang tinggi berarti bahwa perusahaan memiliki lebih sedikit uang dalam bisnisnya. Menurut (Khan et al., 2016) Perusahaan dengan dividen tinggi cenderung menarik investor yang lebih menyukai aliran pendapatan yang dijamin konstan daripada harga pertumbuhan saham yang tinggi. Sebaliknya, perusahaan dengan pembayaran dividen yang rendah berarti perusahaan akan kembali dalam pertumbuhan bisnis, sehingga keuntungan modal masa depan yang lebih tinggi bagi investor. Kebijakan dividen juga mempengaruhi program pendanaan perusahaan dan anggaran modal untuk sumber pendanaannya. Kinerja keuangan merupakan salah satu faktor yang diperkirakan akan mempengaruhi rasio pembayaran dividen (Adi Yuniarta, 2014).

Terlepas dari beberapa penelitian, penelitian sebelumnya menunjukkan perbedaan dampak kebijakan terhadap kinerja keuangan perusahaan. Beberapa ahli percaya bahwa kebijakan dividen memiliki dampak yang signifikan dan positif terhadap kinerja keuangan misalnya (Ali et al., 2015). Beberapa lainnya melaporkan bahwa kebijakan dividen berdampak signifikan namun negatif terhadap kinerja perusahaan (Onanjiri \& Korankye, 2014).

Tujuannya adalah untuk mengetahui dampak dari kebijakan dividen (diwakili oleh jumlah dividen dan keputusan untuk membayar dividen) terhadap kinerja perusahaan. Temuan dari ini dapat berkontribusi pada literatur dengan mengkonfirmasi penelitian sebelumnya. Selain itu, dapat membantu manajer perusahaan menetapkan dividen untuk perusahaan publik yang dapat menyatukan arus kas dan kinerja keuangan mereka (Nguyen et al., 2021). Para ahli mendefinisikan kinerja keuangan perusahaan sebagai analisis untuk mengetahui sejauh mana perusahaan menerapkan aturan praktik keuangannya. Leverage yang lebih besar memiliki efek positif ketika pendapatan dari penggunaan dana ini melebihi biayanya (Fahmi, 2011). 


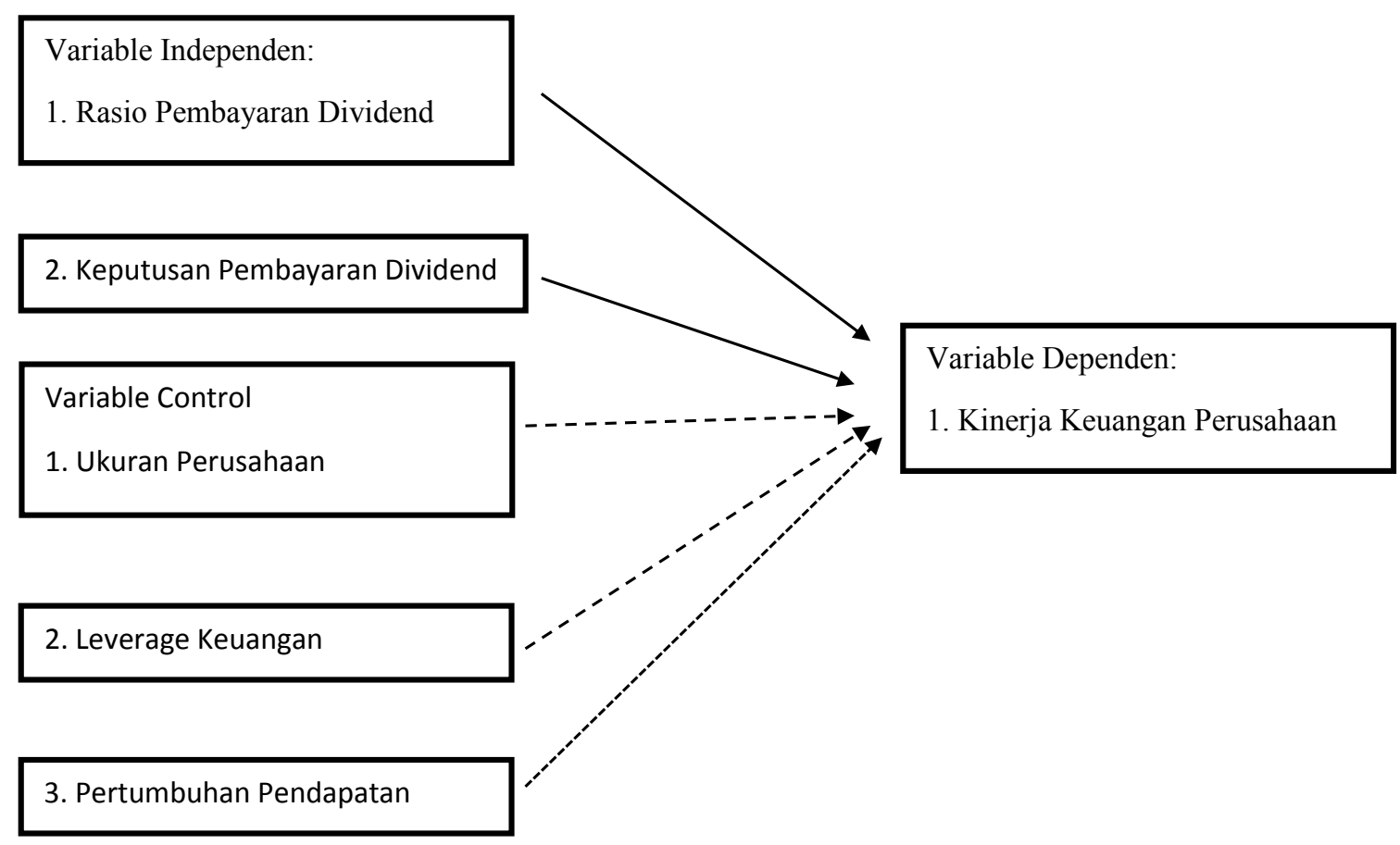

Gambar 1. Rerangka Konseptual

Sumber : (Nguyen et al., 2021)

\section{METODOLOGI}

Rancangan Penelitian. Menggunakan pengujian hipotesis untuk menguji pengaruhnya antara variable independennya yaitu keputusan pembayaran dividen dan dividend payout ratio serta variable control yang mencakup ukuran perusahaan, leverage, pertumbuhan pendapatan terhadap variabel dependennya yaitu kinerja keuangan perusahaan yang diproksikan memakai return on asset (ROA). Perusahaan yang dianalis di penelitian ini dari sektor manufaktur jelang periode 2016-2020 sudah terdaftar di Bursa Efek Indonesia. Penelitian ini akan diuji dan diolah menggunakan software Eviews.

Variabel dan Pengukuran. Variabel dependennya yaitu kebijakan dividen sedangkan variabel independennya antara lain keputusan pembayaran dividen dan dividend payout ratio serta variable control yang mencakup ukuran perusahaan, leverage, growth. Pengukuran untuk masing-masing variabel dapat dilihat di tabel dibawah ini. 
Tabel 1. Variabel dan Pengukurannya

\begin{tabular}{|c|c|c|c|c|}
\hline Jenis Variabel & Variabel & Simbol & Pengukurannya & Sumber \\
\hline $\begin{array}{c}\text { Variabel } \\
\text { Dependen }\end{array}$ & $\begin{array}{c}\text { Kinerja keungan } \\
\text { perusahaan }\end{array}$ & ROA & $\frac{\text { Net Income }}{\text { Total Asset }}$ & $\begin{array}{c}\text { (Nguyen et al., } \\
2021)\end{array}$ \\
\hline \multirow{5}{*}{$\begin{array}{c}\text { Variabel } \\
\text { Independen }\end{array}$} & $\begin{array}{l}\text { Dividend payout } \\
\text { ratio }\end{array}$ & DPR & $\frac{\text { Dividend per share }}{\text { Earning per share }}$ & \multirow{5}{*}{$\begin{array}{c}\text { (Nguyen et al., } \\
\text { 2021) }\end{array}$} \\
\hline & $\begin{array}{c}\text { Decision of } \\
\text { dividend payment }\end{array}$ & DDP & Variabel dummy & \\
\hline & Firm Size & SIZE & $\mathrm{L}_{\mathrm{n}}$ Total Asset & \\
\hline & Leverage & LEV & $\frac{\text { Total Debt }}{\text { Total Asset }}$ & \\
\hline & Growth & GROWTH & $\frac{T A t-T A t-1}{T A t-1}$ & \\
\hline
\end{tabular}

Metode Pengumpulan Data. Data sekunder merupakan data yang digunakan terhadap penelitian ini yaitu diperoleh secara tidak langsung. Sumber yang digunakan untuk memenuhi data sekundernya yaitu didapatkan dari website BEI (http://www.idx.co.id). Datanya yaitu terdiri dari perusahaan bidang manufaktur selama periode 2016-2020. Data akan diolah dan diuji menggunakan software Eviews.

Metode Penerikan Sampel. Penarikan sampel pada penelitian ini yaitu dengan cara purposive sampling atau telah memenuhi beberapa kriteria tertentu. Kriteria-kriteria tersebut antara lain:

Tabel 2. Kriteria Pengambilan Sampel

\begin{tabular}{l|l|l}
\hline No & \multicolumn{1}{|c}{ Kriteria } & \multicolumn{1}{|c}{ Jumlah } \\
\hline 1 & $\begin{array}{l}\text { Perusahaan dari sektor manufaktur yang telah terdaftar di Bursa Efek } \\
\text { Indonesia dari 2016 - 2020 }\end{array}$ & 196 \\
\hline 2 & Perusahaan dari sektor manufaktur yang baru listing di tahun 2016 & $(97)$ \\
\hline 3 & $\begin{array}{l}\text { Perusahaan dari sektor manufaktur yang menggunakan mata asing pada } \\
\text { laporan tahunannya }\end{array}$ & $(7)$ \\
\hline 4 & $\begin{array}{l}\text { Perusahaan dari sektor manufaktur yang laporang keuangannya tidak } \\
\text { lengkap }\end{array}$ & $(22)$ \\
\hline
\end{tabular}




\begin{tabular}{l|l|l}
\hline 5 & $\begin{array}{l}\text { Perusahaan dari sektor manufaktur yang tidak membagikan dividen pada } \\
\text { periode 2016 - 2020 }\end{array}$ & (33) \\
\hline & Jumlah data yang diperolah untuk dijadikan sampel & $(37)$ \\
\hline
\end{tabular}

Uji Model. Metode pengujuan analisis regresi data panel digunakan pada penelitian ini dengan melakukan pengujian tiga model antara lain model common effect, fixed effect, dan random effect. Terdapat dua langkah pengujian untuk dilakukan dalam menentukan model yang dipilih agar tepat saat diinterpretasikan, yaitu Uji Chow dan Uji Hausman.

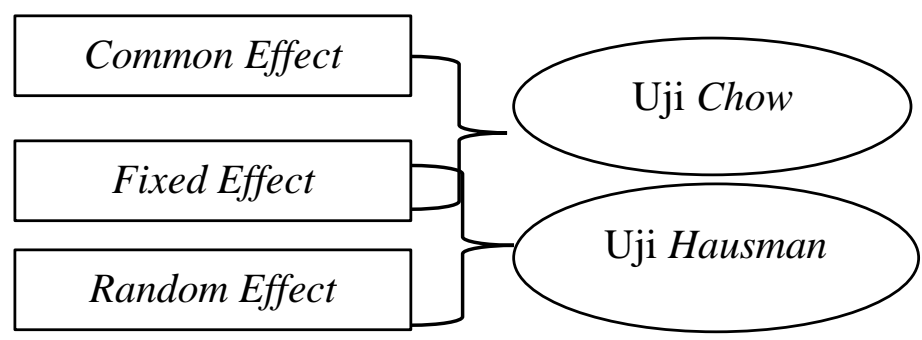

Gambar 2. Model Data Panel

Berikut ini langkah-langkah pengujian data panel:

Uji Chow. Uji Chow adalah pengujian yang digunakan untuk menentukan model mana yang lebih tepat digunakan di antara efek yang cocok atau tetap. Uji Chow didasarkan pada hipotesis nol heterogenitas individu dan hipotesis alternatif bahwa ada heterogenitas crosssectional. Hipotesis pada pengujian ini yaitu:

H0: Common effect model menjadi model yang tepat untuk digunakan Ha: Fixed effect model menjadi model yang tepat untuk digunakan Kriteria pengambilan keputusannya:

Tabel 3. Hasil Uji Chow

\begin{tabular}{c|c|c|c}
\hline Dependen & Chi-square & Prob & Keputusan \\
\hline ROA & 417.709432 & 0.0000 & Ditolak $\mathrm{H}_{0}$, Fixed Effect terpilih \\
\hline
\end{tabular}

Tabel hasil uji chow menunjukkan hasil yang diperoleh cross section Chi-squarenya sebesar $0.0000<0.05$, artinya $\mathrm{H} 0$ ditolak dan model yang dipilih untuk digunakan adalah Fixed effect. Selanjutnya karena fixed effect model yang dipilih, uji hausman dilakukan untuk diuji model fixed effect atau random effect yang akan digunakan.

Uji Hausman. Tes Hausman adalah tes yang digunakan untuk memilih di antara mereka. 
Dalam penelitian ini, dua model, efek tetap dan efek acak, digunakan lebih baik dan lebih lengkap. Uji Hausman menghitung fitur dari setiap model untuk menentukan apakah model tersebut memiliki heterogenitas. Hipotesis dalam uji Hausman dapat ditulis sebagai berikut:

H0 : Model yang digunakan random effect model.

Ha : Model yang digunakan fixed effect model.

Kriteria pengambilan keputusan:

1) chi-square $<\mathrm{a}=0.05$ berarti $\mathrm{H} 0$ ditolak.

Model yang paling tepat digunakan adalah fixed effect model.

2) chi-square $>\mathrm{a}=0.05$ berarti $\mathrm{H} 0$ diterima.

Model yang digunakan adalah random effect model

Tabel 4. Hasil Hausman Test

\begin{tabular}{c|c|c|c}
\hline Dependen & Chi-square & Prob & Keputusan \\
\hline ROA & 17.090154 & 0.0043 & Ditolak $\mathrm{H}_{0}$, Fixed Effect terpilih \\
\hline
\end{tabular}

Hasil yang ditunjukkan probabilita cross-sectionnya sebesar $0.0043<0.05$, H0 ditolak sehingga dapat diambil keputusan bahwa fixed effect model menjadi model yang cocok untuk digunakan.

Uji F. Berguna untuk menilai kelayakan model regresi pada penelitiian ini. Berfungsi untuk mengatahui keterkaitan pengaruhnya antara variabel indepen dan dependen yang digunakannya.

Tabel 5. Hasil F test

\begin{tabular}{c|c|c|c}
\hline Dependen & F-Statistic & Prob & Keputusan \\
\hline ROA & 39.65002 & 0.000000 & Ditolak $\mathrm{H}_{0}$ \\
\hline
\end{tabular}

Hasil tabel uji f menunjukan besaran nilai prob uji F sebesar $0.000000<0.05$. Artinya secara bersama-sama semua variabel independen yang terdiri dari dividend payout ratio, dividend payment decision, firm size, leverage dan pertumbuhan pendapatan ada pengaruhnya terhadap return on asset, berarti model regresi layak untuk digunakan.

Uji Goodness of Fit (Adjusted $\mathbf{R}^{2}$ ). Uji goodness of fit dilakukan guna melihat besaran peran variabel independennya dalam mejelaskan bagaiamana variabel dependennya mengalami perubahan. Nilai adjusted $\mathrm{R}^{2}$ dinyatakan dalam 0 hingga $1\left(0<\mathrm{R}^{2}<1\right)$.

Tabel 6. Hasil Uji Goodness of Fit

\begin{tabular}{c|c|c}
\hline Dependen & $\mathrm{R}^{2}$ & Adjusted $^{2}$ \\
\hline ROA & 0.919147 & 0.895966 \\
\hline
\end{tabular}


Hasil yang menunjukkan nilai adjusted r-square sebesar 0.895966. Variabel independennya yaitu dividend payout ratio, dividend payment decision, firm size, leverage dan pertumbuhan pendapatan dapat menjelaskan perubahan variasi dari return on asset sebesar $89.5966 \%$ dan sisanya sebesar $10.4034 \%$ artinya perubahan return on asset dapat dipengaruhi faktor lainnya. Dapat disimpulkan adanya pengaruh yang kuat antar variabel independent terhadap dependennya.

\section{Metode Analisis Data}

Analisis Regresi Linear Berganda. Metode analisis regeresi linear berganda digunakan untuk mengetahui pengaruhnya antara variable independen yaitu keputusan pembayaran dividen dan dividend payout ratio serta variable control yang mencakup ukuran perusahaan, leverage, growth terhadap variabel dependennya yaitu kinerja keuangan perusahaan.

Model:

$$
\text { ROAi, } t=\beta 0+\beta 1 \text { DPRi, } t+\beta 2 i, t+\beta 3 \text { SIZEi, } t+\beta 4 \text { LEVi, } t+\beta 5 \text { GROWTHi, } t+\varepsilon 1
$$

Keterangan:

$\mathrm{ROA}_{\text {it }} \quad=$ indikator Kinerja keuangan

$\mathrm{DPR}_{\mathrm{it}} \quad=$ Dividend payout ratio

it $\quad=$ Dividend decisions payment

SIZE $_{\text {it }} \quad=$ Ukuran Perusahaan

$\mathrm{LEV}_{\text {it }} \quad=$ Leverage

GROWTH $_{\text {it }} \quad=$ Pertumbuhan pendapatan

Statistik deskriptif. Karakteristik suatu data yang dipakai dalam penelitian berdasarkan nilai mean, maksimum, minimum, dan standar deviasi. Nilai maksimum yaitu nilai tertinggi dari setiap variabel, setelah itu ada nilai minimum yaitu nilai terendah dari setiap variabel pada penelitian, terakhir ada standar deviasi yaitu ukuran dari sebaran data yang dipergunakan untuk melihat apakah data tersebut homogen atau heterogen.

Uji T. Uji t merupakan pengujian analisis yang bertujuan menguji apakah masing-masing variabel independent yaitu keputusan pembayaran dividen dan dividend payout ratio serta variable control yaitu ukuran perusahaan, leverage, pertumbuhan pendapatan terhadap variabel dependennya yaitu kinerja keuangan (ROA) perusahaan menggunakan tingkat signifikasi $5 \%$.

Kriterianya sebagai berikut: (1) Apabila sig dari $\mathrm{t}<0.05$ artinya H0 ditolak. Ada pengaruhnya variabel independent dengan variabel dependen. (2) b. Apabila sig dari t > 0.05 artinya $\mathrm{H} 0$ diterima, tidak ada pengaruhnya variabel independent dengan variabel dependen. 


\section{HASIL DAN PEMBAHASAN}

Deskripsi Objek Penelitian. Objek penelitian menggunakan perusahaan manufaktur yang telah terdaftar pada periode 2016-2020 di BEI dan telah membayarkan dividen selama periode tersebuty yaitu sebanyak 37 perusahaan. Penelitian ini menggunakan data sekunder yaitu laporan tahunan perusahaan. Metode pengambilan sampel menggunakan purposive sampling berdesarkan beberapa kriteria seperti melakukan pembayaran dividen dalam kurun waktu 2016 sampai 2020 dan didapatkan 37 sampel perusahaan.

Analisis Statistik Deskriptif. Analisis statistik deskriptif untuk menentukan perhitungan mean (mean), standar deviasi (standar), minimum dan maksimum. Tabel hasil analisis yang diperoleh dari statistik deskriptif untuk masing-masing variabel adalah sebagai berikut:

Tabel 7. Hasil Analisis Deskriptif

\begin{tabular}{l|l|l|l|l}
\hline Variabel & Minimun & Maximum & Mean & $\begin{array}{l}\text { Standar } \\
\text { Deviasi }\end{array}$ \\
\hline ROA & -0.124000 & 0.446800 & 0.080843 & 0.087456 \\
\hline $\begin{array}{l}\text { Dividend Payout } \\
\text { Ratio }\end{array}$ & -1.973100 & 2.611000 & 0.412831 & 0.421015 \\
\hline $\begin{array}{l}\text { Decision of } \\
\text { dividend payment }\end{array}$ & 0.000000 & 1.000000 & 0.913514 & 0.281844 \\
\hline Firm Size & 11.15680 & 14.54650 & 12.68871 & 0.712059 \\
\hline Leverage & 0.076900 & 0.864900 & 0.384693 & 0.188623 \\
\hline Growth & -0.241300 & 1.676100 & 0.106494 & 0.212118 \\
\hline
\end{tabular}

Regresi Berganda. Menggunakan model regresi berganda guna menguji apakah ada pengaruhnya antara Dividend payout ratio (DPR), Dividend decisions payment (DDP), Firm Size (SIZE) Leverage (LEV) dan Pertumbuhan pendapatan (GROWTH) terhadap kinerja perusahaan (ROA). Berikut ini adalah analisis regresinya:

ROAi, $\mathrm{t}=0.880370+-0.000843$ DPRi, $\mathrm{t}+0.046316$ DDPi, $\mathrm{t}+-0.064145$ SIZEi, $\mathrm{t}+-$ 0.075792 LEVi,t +0.014867 GROWTHi, $t+\varepsilon 1$ 


\section{Uji T atau Uji Parsial}

Tabel 8. Hasil Uji T

\begin{tabular}{c|c|c|c}
\hline \multirow{2}{*}{$\begin{array}{c}\text { Variabel } \\
\text { Independen }\end{array}$} & \multicolumn{3}{|c}{ Variabel Dependen } \\
\cline { 2 - 4 } & Koefisien & Probabilitas & Kesimpulan \\
\cline { 2 - 4 } Konstanta & 0.880370 & - & - \\
\hline DPR & -0.000843 & 0.9116 & Tidak Signifikan \\
\hline DDP & 0.046316 & 0.0000 & Positif Signifikan \\
\hline SIZE & -0.064145 & 0.0455 & Negatif Signifikan Signifikan \\
\hline LEVERAGE & -0.075792 & 0.0215 & Tidak Signifikan \\
\hline GROWTH & 0.014867 & 0.2186 &
\end{tabular}

Pengembalian keputusannya diuraikan menjadi sebagai berikut :

H1: Ada pengaruh antara dividend payout ratio dengan kinerja keuangan perusahaan.

Rasio pembayaran dividen dengan probabilitas 0,9116>0,05 (alpha 5\%) tidak berpengaruh. Hasil penelitian ini menyimpulkan bahwa dividend payout ratio tidak berpengaruh terhadap return on assets.

H2: Ada pengaruh antara dividend payout ratio dengan kinerja keuangan perusahaan.

Dengan probabilitas $0,0000<0,05$ (alpha 5\%), keputusan membayar dividen berpengaruh signifikan. Ini memiliki nilai koefisien 0,046316. Hasil penelitian ini menyimpulkan bahwa keputusan membayar dividen berpengaruh positif signifikan terhadap return on assets.

H3: Ada pengaruh antara ukuran perusahaan dengan kinerja keuangan perusahaan.

Ukuran perusahaan berpengaruh signifikan dengan probabilitas 0,0455 <0,05 (alpha 5\%). Ini memiliki nilai koefisien -0,064145. Hasil penelitian ini menyimpulkan bahwa ukuran perusahaan berpengaruh negatif signifikan terhadap return on assets.

H4: Ada pengaruh antara leverage dengan kinerja keuangan perusahaan.

Leverage dengan probabilitas $0,0215<0,05$ (alpha 5\%) menunjukkan pengaruh yang signifikan. Ukuran koefisiennya adalah -0,075792. Hasil penelitian ini menyimpulkan bahwa terdapat pengaruh negatif yang signifikan dari leverage terhadap return on assets.

H5: Ada pengaruh antara pertumbuhan perusahaan dengan kinerja keuangannya.

Pertumbuhan aset dengan probabilitas 0,2186 > 0,05 (alpha 5\%), yang berarti tidak berpengaruh. Hasil penelitian ini menyimpulkan bahwa pertumbuhan aset tidak berpengaruh terhadap return on assets. 


\section{DISKUSI}

H1: Dividend payout ratio berpengaruh terhadap kinerja keuangan perusahaan. Berdasarkan penelitian, ditemukan bahwa tidak terdapat pengaruh yang signifikan antara dividend payout ratio dengan kinerja keuangan perusahaan yang diukur dengan ROA. Bertentangan dengan apa yang telah dipelajari (Nguyen et al., 2021) mereka menemukan adanya pengaruh positif signifikan antara dividend payout ratio terhadap kinerja keuangan perusahaan.

H2: Dividend decisions payment berpengaruh terhadap kinerja keuangan perusahaan. Berdasarkan penelitian yang dilakukan terdapat hasil yang menunjukkan bahwa decision of dividend payment berpengaruh positif signikan terhadap kinerja keuangan perusahaan (ROA).

H3: Firm Size berpengaruh terhadap kinerja keuangan perusahaan. Dari hasil yang sudah dicari ditemukan bahwa ada pengaruh significant negatif antara ukuran perusahaan dengan ROA atau kinerja keungan perusahan. Sesuai pada hasil penelitian yang diperoleh dari (Nguyen et al., 2021) mereka menemukan pengaruh negatif signikan antara variabel decision of dividend payment kepada kinerja keuangannya perusahaan (ROA)

H4: Leverage berpengaruh terhadap kinerja keuangan perusahaan. Berdasarkan penelitian yang dilakukan ditemukan hasil adanya pengaruh significant negatif antara leverage dengan kinerja keuangan perusahaan (ROA). Tidak sejalan pada penelitian (Nguyen et al., 2021) yang mendapatkan hasil penelitian terdapat pengaruh negatif dan signikan leverage terhadap kinerja keuangan (ROA).

H5: Growth berpengaruh terhadap kinerja keuangan perusahaan. Berdasarkan hasil penelitian yang telah dilakukan ditunjukkan bahwa growth tidak memiliki pengaruh significant terhadap kinerja keuangan perusahaan (ROA). Hasil penelitiannya berbeda dengan penelitian yang diperoleh (Nguyen et al., 2021) yaitu ditemukan bahwa variabel growth memiliki pengaruh negatif dan signifikan terhadap kinerja keuangan perusahaan (ROA).

\section{KESIMPULAN}

Berdasarkan pada hasil yang telah diperoleh dalam penelitian ini, ada variabel independent pada penelitian ini yang tidak memiliki pengaruh yang signifikan yaitu dividend payout ratio terhadap kinerja keungan perusahaan dan growth terhadap kinerja keuangan perusahaan. Artinya informasi tentang rasio dividen tidak mempengaruhi kinerja keuangan perusahaan manufaktur, begitu juga dengan pertumbuhan pendapatan suatu perusahaan tidak mempengaruhi kinerja keuangan perusahaan pada sektor manufaktur. Pada variabel dividend decision payment diperoleh hasil bahwa terdapat pengaruh positif signifikan sedangkan pada firm size dan leverage berpengaruh negatif signifikan. Artinya pertumbuhan DDP akan mempengaruh tumbuhnya kinerja keuangan perusahaan. 


\section{DAFTAR PUSTAKA}

Adi Yuniarta Jurusan Akuntansi, G., \& Ekonomi dan Bisnis, F. (2014). Pengaruh Kinerja Keuangan Dan Pertumbuhan Perusahaan Terhadap Deviden Payout Ratio.

Ali, A., Jan, F. A., \& Atta, M. (2015). The Impact of Dividend Policy on Firm Performance under High or Low Leverage; Evidence from Pakistan. Journal of Management Info, 2(4), 16-25. https://doi.org/10.31580/jmi.v8i1.48

Arnott, R. D., \& Asness, C. S. (2003). Surprise! Higher Dividends = Higher Earnings Growth. 1961.

Bisnis, J., \& Akuntansi, D. (2011). Faktor-Faktor Yang Mempengaruhi Struktur Modal Pada Perusahaan Publik Sektor Manufaktur Seftianne Alumnus Stie Trisakti Ratih Handayani (Vol. 13, Issue 1).

Deni Sunaryo. (2018): Pengaruh Utang Jangka Pendek Dan Utang Jangka Panjang Terhadap Profitabilitas Pada Perusahaan Industri Makanan Dan Minuman Yang Terdaftar Di Bursa Efek Indonesia (BEI) Periode Tahun 2013-2017. Sains Manajemen. Vol. 4 No. 1.

Dewi, N. W. A. M., \& Candradewi, M. R. (2018). Pengaruh Employee Stock Ownership Plan, Leverage, Dan Ukuran Perusahaan Terhadap Kinerja Keuangan Perusahaan. E$\begin{array}{llll}\text { Jurnal Manajemen Universitas } & 4774 .\end{array}$ https://doi.org/10.24843/EJMUNUD.2018.v07.i09.p06

Dharma, M. I., Hermanto, B., \& Fordiani, D. (2020). Jurnal Politeknik Caltex Riau Rasio Pembayaran Dividen pada Subsektor Industri Pariwisata, Hotel , dan Restoran Tahun 2013-2017. 13(2), 70-77.

Fahmi, I. (2011). Analisis Kinerja Keuangan Dalam Perspektif Rasio Likuiditas Pada Keputusan Sebelum Dan Sesudah Right Issue. Gema, II(2), 11-23.

Farahani, M. H., \& Ghara Jhafari, M. (2013). Impact of Financial Leverage on Dividend Policy at Tehran Stock Exchange: A Case Study in Food Industry. European Online Journal of Natural and Social Sciences, 2(3). www.european-science.com

Indra Widjaja, S. A. D. (2019). Pengaruh Working Capital Turnover, Total Asset Turnover, Asset Growth Dan Sales Growth Terhadap Kinerja Keuangan Perusahaan Consumer Goods Yang Terdaftar Di Bursa Efek Indonesia Selama Tahun 2013-2016. Jurnal Manajemen Bisnis Dan Kewirausahaan, 2(2), 57-66. https://doi.org/10.24912/jmbk.v2i2.4829

Jensen, M. C., \& Meckling, W. H. (1976). Theory Of The Firm: Managerial Behavior, Agency Costs And Ownership Structure. In Journal of Financial Economics (Vol. 3). Q North-Holland Publishing Company.

Khan, M. N., Naeem, M. U., Rizwan, M., \& Salman, M. (2016). Factors Affecting the Firm Dividend Policy: An Empirical Evidence from Textile Sector of Pakistan. International Journal of Advanced Scientific Research and Management, 1(5), 144149.

Kouser, R., Bano, T., \& Azeem, M. (2012). Inter-Relationship between Profitability , Growth and Size: A Case of Non- Financial Companies from Pakistan. Pakistan Journal of Commerce and Social Sciences, 6(2), 405-419. 
Litzenberger, R. H., Ramaswamy, K., Introduction, I., \& Bi, E. (1982). The Effects of Dividends on Common Stock Prices Tax Effects or Information Effects? XXXVII(2).

Matar, A., \& Eneizan, B. (2018). Determinants of Financial Performance in the Industrial Firms: Evidence from Jordan. Asian Journal of Agricultural Extension, Economics \& Sociology, 22(1), 1-10. https://doi.org/10.9734/ajaees/2018/37476

Nguyen, A. H., Pham, C. D., Doan, N. T., Ta, T. T., Nguyen, H. T., \& Truong, T. Van. (2021). The Effect of Dividend Payment on Firm's Financial Performance: An Empirical Study of Vietnam.

Noor Salim, M., \& Pandji Ibnul Djausin, R. (2020). Determinants of Financial Performance and its Impact on the Growth of Islamic Bank Assets on Indonesia. International Journal of Business, Economics and Management, 7(1), 27-41. https://doi.org/10.18488/journal.62.2020.71.27.41

Onanjiri, R. N., \& Korankye, T. (2014). Dividend Payout and Performance of Quoted Manufacturing Firms in Ghana. In Research Journal of Finance and Accounting www.iiste.org ISSN (Vol. 5, Issue 15). www.iiste.org

Ping, Z., \& Ruland, W. (2006). Dividend payout and future earnings growth. Financial Analysts Journal, 62(3), 58-69. https://doi.org/10.2469/faj.v62.n3.4157

Prasetia, T. E., Tommy, P., \& Saerang, I. S. (2014). Capital Structure, Company Size, and Company Risk of the Value of Automotive Companies Listed on the IDX. EMBA Journal, 2, 879-889.

Ritonga, M., Sri, K., \& Rahayu, M. (2014). Pengaruh Financial Leverage Terhadap Profitabilitas (Studi pada Perusahaan Makanan dan Minuman yang Terdaftar pada Bursa Efek Indonesia. In Jurnal Administrasi Bisnis (JAB)| (Vol. 8, Issue 2).

Silvestro, R. (2014). Performance topology mapping: Understanding the drivers of performance. International Journal of Production Economics, 156, 269-282. https://doi.org/10.1016/j.ijpe.2014.05.011

Ullah, K., \& Bagh, T. (2020). Finance and Management Scholar at Riphah International University Islamabad, Pakistan, Faculty of Management Sciences. April. https://doi.org/10.7176/RJFA 